\title{
Reparation by Hard Facing of the Damaged Secondary Stone Crushers
}

\author{
Vukić Lazić ${ }^{1}$, Dušan Arsić ${ }^{1, *}$, Ružica Nikolić1,2, Milan Mutavdžić3, Jozef Meško ${ }^{4}$ \\ ${ }^{1}$ Faculty of Engineering, University of Kragujevac, Sestre Janjić 6, Str., 34000 Kragujevac, Serbia, \\ E-mails: vlazic@kg.ac.rs; dusan.arsic@fink.rs (corresponding author); \\ ${ }^{2}$ Research center, University in Žili na, Univerzitna 8215/1, 01026 Žilina, Slovakia; E-mail: ruzicarnikolic@yahoo.com \\ ${ }^{3}$ High Technical School, 24. November bb, 38218 Leposavić, Serbia; E-mail: mutavdzicmilan57@gmail.com \\ ${ }^{4}$ Faculty of Mechanical Engineering, University in Žilina, Univerzitna 8215/1, 01026 Žilina, Slovakia; \\ E-mail: Jozef.Mesko@fstroj.uniza.sk
}

The possibilities for reparation by hard facing of the damaged working parts - the hammers of the secondary stones crusher are investigated in this paper. The analyzed crusher is stationary and it belongs into a group of the process equipment aimed for producing the crushed stone. The produced stone is later used for manufacturing various construction materials like asphalt, concrete, etc. Wear of the crusher's working parts occurs during the exploitation due to operation with very hard materials. That wear is usually abrasive and of high intensity what causes failure of the working parts and consequently the machine's downtimes and appearance of various types of losses, primarily financial ones. To prevent that, and to reduce the downtimes as well, one uses reparation technologies, one of which is hard facing. The analysis of the mass losses of the hard faced parts, after certain number of hours of the crusher's field operation, is performed in this paper.

Keywords: Reparation, Hard facing, Hammer, Secondary crusher

\section{Acknowledgement}

This research was partially financially supported by European regional development fund and Slovak state budget by the project "Research Centre of the University of Žilina" - ITMS 26220220183 and by the Ministry of Education, Science and Technological Development of Republic of Serbia through grants: ON174004, TR32036, TR35024 and TR33015 and VEGA - project no. 1/0836/13 "Technological aspects of the laser cutting process, numerical modeling and simulation in terms of optimalization, improve the quality and efficiency of production processes." Responsible investigator: prof. Jozef Meško, MSc., Ph.D.

\section{References}

[1] NEDELJKOVIĆ, B., BABIĆ, M., MUTAVDŽIĆ, M., RATKOVIĆ, N., ALEKSANDROVIĆ, S., NIKOLIĆ, R., LAZIĆ, V. (2008). Reparatory hard facing of the rotational device knives for terrain leveling. Journal of the Balkan Tribological Association, Vol. 16, No. 1, pp. 46-57. Bulgaria.

[2] LAZIĆ, V., JOVANOVIĆ, M., MILOSAVLJEVIĆ, D., MUTAVDŽIĆ, M., ČUKIĆ, R. (2008). Choosing of the most suitable technology of hard facing of mixer blades used in asphalt bases. Tribology in industry, Vol. 30, No. $1 \& 2$, pp 3-10. Serbia.

[3] MARKOVIĆ, S., MILOVIĆ, LJ., MARINKOVIĆ, A., LAZOVIĆ, T. (2011). Tribological aspect of selecting filler metal for repair surfacing of gears by hard facing. Structural Integrity and Life, Vol. 11, No. 2, pp. 127-130. Serbia.

[4] LAZIĆ, V., SEDMAK, A., ALEKSANDROVIĆ, S., MILOSAVLJEVIĆ, D., ČUKIĆ, R., GRABULOV, V. (2009). Reparation of damaged mallet for hammer forging by hard facing and weld cladding. Tehnički VjesnikTechnical Gazette, Vol. 16, No. 4, pp. 107-113. Croatia.

[5] HAWRYLUK, M., MARCINIAK, M., MISIUN, G. (2014). Possibilities of investigating abrasive wear in conditions close to those prevailing in industrial forging processes. Eksploatacja i Niezawodnosc-Maintenance and Reliability, Vol. 16, No. 4, pp. 600-607. Poland.

[6] ARSIĆ, M., BURZIĆ, M., KARIĆ, R. M., VISTAĆ, B., SAVIĆ, Z. (2014). Methodology for repairing defects on internal surfaces of cranks of guide vane apparatus in hydroelectric generating set at hydropower plant Djerdap 1. Structural Integrity and Life, Vol. 14, No.2, pp. 121-124. Serbia.

[7] KANG, S., CHEEMAA, G.S., SINGLA, S. (2014). Wear behavior of hard facings on rotary tiller blades. Procedia Engineering, Vol. 97, pp. 1442-1451. The Netherlands.

[8] LAZIĆ, V., MUTAVDŽIĆ, M., MILOSAVlJEVIĆ, D., ALEKSANDROVIĆ, S., NEDELJKOVIĆ, B., MARINKOVIĆ, P., ČUKIĆ, R. (2011). Selection of the most appropriate technology of reparatory hard facing of working parts on universal construction machinery. Tribology in industry, Vol. 33, No. 1, pp. 18-27. Serbia. 
[9] LAZIĆ, V., SEDMAK, A., NIKOLIĆ, R., MUTAVDZIĆ, M., ALEKSANDROVIĆ S., KRSTIĆ B., MILOSAVLJEVIĆ D. (2015). Selection of the most appropriate welding technology for hard facing of bucket teeth. Materiali in Tehnologije, Vol. 49, No. 1, pp. 165-172. Slovenia.

[10]ARSiĆ, D., LAZIĆ, V., MITROVIĆ, S., DŽUniĆ, D., ALEKSANDROVIĆ, S., NEDELJKOVIĆ, B., DJORDJEVIĆ, M. (2016). Tribological behavior of four types of filler metals for hard facing under dry conditions. Industrial Lubrication and Tribology, Vol. 68, (accepted paper). United Kingdom.

[11]ARSIĆ, D., LAZIĆ, V., NIKOLIĆ, R. R., MUTAVDŽIĆ, M., ALEKSANDROVIĆ, S., DJORDJEVIĆ, M. (2016). Influence of the sliding speed on the wear resistance of parts which operate in conditions without lubrication hard faced by the high-alloyed filler metal. Materials Engineering/Materialove inzinierstvo, Vol. 23, (in press). Slovakia.

[12]MUTAVDŽIĆ, M., ČUKIĆ, R., JOVANOVIĆ, M., MILOSAVLJEVIĆ, D., LAZIĆ, V. (2008). Model investigations of the filler materials for regeneration of the damaged parts of the construction. Tribology in industry, Vol. 30, No. 3\&4, pp. 3-9. Serbia.

[13]ARSIĆ, D., LAZIĆ, V., SAMARDŽIĆ, I., NIKOLIĆ, R., ALEKSANDROVIĆ, S., DJORDJEVIĆ, M., HADZIMA, B. (2015). Impact of the hard facing technology and the filler metal on tribological characteristics of the hard faced forging dies. Tehnički Vjesnik - Technical Gazette, Vol. 22, No. 5, pp. 1353-1358. Croatia.

[14]LAZIĆ, V., ARSIĆ, D., NIKOLIĆ, R., HADZIMA, B., MUTAVDŽIĆ, M. (2015). Experimental determination of mechanical characteristics of four types of stones and their influence on the construction machinery parts wear. Advanced Materials Research, Vol. 1100, pp. 178-184. TTP Switzerland.

[15]ZAVOS, A., NIKOLAKOPOULOS, P. (2015). Tribological characterization of smooth and artificially textured coated surfaces using block-on-ring tests. FME Transactions, Vol. 43, No. 3, pp. 191-197. Serbia.

[16]CUI, G., WEI, J., WU, G. (2015). Wear behavior of Fe-Cr-B alloys under dry sliding condition. Industrial Lubrication and Tribology, Vol. 67, No. 4, pp. 336-343. United Kingdom.

[17]VARGA, M., WINKELMANN, H., BADISCH, E. (2011). Impact of microstructure on high temperature wear resistance. Procedia Engineering, Vol. 10, pp. 1291-1296. The Netherlands.

[18]CHANG, Y. CHEN, W. WU. (2010). Microstructural and abrasive characteristics of high carbon Fe-Cr-C hard facing alloy. Tribology International, Vol. 43, No. 5-6, pp. 929-934. The Netherlands.

[19]ŻUROWSKI, W. (2012). Structural factors contributing to increased wear resistance of steel friction couples. Eksploatacja i Niezawodnosc - Maintenance and Reliability, Vol. 14, No. 1, pp. 19-23. Poland.

[20]Catalogues of base and filler metals: Steel plant Jesenice, Slovenia; EN Standards, European Union; DIN normen. Germany. 